\title{
ANALISIS FAKTOR-FAKTOR YANG MEMPENGARUHI AUDIT DELAY PELAPORAN KEUANGAN PADA PERUSAHAAN MANUFAKTUR YANG TERDAFTAR DI BURSA EFEK INDONESIA
}

\author{
Oleh: \\ Hormaingat Damanik ${ }^{1)}$ \\ Sarman Sinaga ${ }^{2)}$ \\ Renungkan Buulolo ${ }^{3)}$ \\ Universitas Darma Agung, Medan 1,2,3) \\ E-mail: \\ $\frac{\text { damanikhormaingat@gmail.com }}{\text { sarmansinaga17@gmail.com }^{2)}}$ \\ renungkan@gmail.com ${ }^{3)}$
}

\begin{abstract}
Audit delay is a delay in submitting or publishing the company's financial statements which can make a financial report quality doubtful by the parties interested in making decisions. Thi study aims at testing and analyzing the effect of profitability, solvency, and KAP size on audit delay in financial report submission in consumer goods industrial sector manufacturing companies listed on the IDX for the period 2017 - 2019. In this study there are 3 independent variables, namely profitabilit, solvency and hood size and the dependent variable there is 1, namely audit delay. The sampling method used in this research is purposive sampling method in which total population in this study is 36 companies and then eighteen (18) companies fulfilled the purposive sampling. The type of regression model used in this study is logistic regression, then to test the research in logistic regression using Statistical Product and Service Solution (SPSS) version 22.0 for windows using simultaneous test (Omnibus Test Of Model Coefficient) and Wald test (partial). The results in this study indicate that together (Simultaneous Test) all independent variables affect audit delay where the Chi-square value is 4.291 with a significance value of $0.032<0.05$, then the hypothesis is accepted. Then in the Wald Test only the KAP size variable affects audit delay significantly where the Wald test value is 2.068 with a significance of $0.048<0.05$, so the hypothesis is accepted. Meanwhile, the profitability and solvency variables have no effect on audit delay where the Wald test value is 0.663>0.05 and 1.187>0.05, so the hypothesis is rejected.
\end{abstract}

Keywords: Profitability, Solvency, KAP Size, Audit Delay.

\begin{abstract}
ABSTRAK
Audit delay merupakan keterlambatandalam menyampaikan atau publikasi laporan keuangan perusahaan yang dapat membuat suatu kualitas laporan keuangan diragukan oleh pihak-pihak yang berkepentingan dalam pengambilan keputusan. Penelitian ini bertujuan untuk mengetahui dan menganalisis pengaruh profitabilitas, solvabilitas, dan ukuran KAP terhadap audit delay pelaporan keuangan pada perusahaan manufaktur sector barang konsumsi yang terdaftar di Bursa Efek Indonesia. Populasi yang digunakan adalah sub sector industry barang konsumsi yang terdaftar di Bursa Efek Indonesia .Metode pengambilan sampel yang dilakukan dalam peneltian ini adalah
\end{abstract}


metode purposive sampling.Jumlah populasi yang terdapat dalam peneltian ini adalah 36 perusahaan dan kemudian yang memenuhi purposive sampling delapan belas (18) perusahaan. Jenis model regresi yang digunakan dalam penelitian ini adalah regresi logistik, kemudian untuk menguji peneltian dalam regresi logistik menggunakan Statistical Product and Service Solution (SPSS) versi 22.0 for windows dengan menggunakan uji simultan (Omnibus Test Of Model Coefficient) dan uji Wald (parsial). Hasil dalam peneltian ini menunjukkan bahwa secara bersama-sama (Uji Simultan) semua variabel independen mempengaruhi audit delay dimana niali dari Chi-square sebesar 4,291 dengan nilai signifikansi sebesar 0,032<0,05, maka Hipotesis diterima. Kemudian dalam Uji Wald hanya variabel Ukuran KAP yang mempengaruhi audit delay secara signifikan dimana nilai uji wald sebesar 2.068 dengan signifikansi sebesar $0,048<0,05$, maka Hipotesis diterima. Sedangkan variabel profitabilitas dan solvabilitas tidak berpengaruh terhadap audit delay dimana nilai uji wald sebesar 0,663>0,05 dan 1,187>0,05, maka Hipotesis ditolak.

\section{Kata Kunci : Profitabilitas, Solvabilitas, Ukuran KAP, Audit Delay.}

\section{PENDAHULUAN}

\subsection{Latar belakang}

Pihak yang berkepentingan terhadap laporan keuangan pada umumnya menginginkan kecepatan waktu pengungkapan laporan keuangan.. Dengan cepatnya laporan keuangan dipublikasikan, maka manfaatnya besar yang diperoleh para pemakai laporan keuangan.Begitu juga sebaliknya, laporan keuangan yang terlambat dipublikasikan akan mengakibatkan ketidakpastian dalam pengambilan keputusan oleh pengguna sehubungan dengan informasi yang ada dalam laporan keuangan.

Audit Delay merupakan lamanya penyelesaian audit yang akan diukur dari tanggal penutupan buku perusahaan hingga tanggal diterbitkannya laporan audit perusahaan. Hal ini akan mengakibatkan lamanya publikasi laporan keuangan selanjutnya akan merugikan para investor dalam membuat keputusan investasi atau pemberian kredit bagi kreditor.Kewajiban penyampaian laporan keuangan yang telah diaudit wajib disampaikan kepada BapepamLK selambat-lambatnya pada akhir bulan ketiga (90 Hari) terhitung sejak tanggal terakhir tahun buku.

Dari berbagai banyak faktor yang mempengaruhi audit delay dalam penyampaian laporan keuangan, peneliti akan menguji 3 (tiga) faktor, yaitu tingkat profitabilitas, solvabilitas dan ukuran KAP.Profitabilitas disebut juga kemampulabaan suatu perusahaan dihunakan untuk mengetahui kemampuan perusahaan dalam mendapatkan laba dari pendapatan.Solvabilitas merupakan kemampuan perusahaan untuk memenuhi semua kewajiban yaitu seperti kemampuan melunasi hutang yang ada dengan menggunakan seluruh asset yang dimilikinya.Ukuran Kantor Akuntan Publik (KAP) perusahaan mempengaruhi audit delay penyampaian laporan keuangan, dimana semakin baik reputasi KAP yang dimiliki perusahaan maka lebih efisien dalam melakukan proses audit laporan keuangan perusahaan.

Berdasarkan penelitian yang dilakukan oleh Jun Peramita Aritonang (2019) menunjukkan bahwa profitabilitas tidak berpengaruh signifikan terhadap audit delay, hal ini berbeda dengan penelitian Rangga Fahmi Hakiki (2018) bahwa 
profitabilitas berpengaruh signifikan terhadap audit delay. Penelitian yang dilakukan oleh Ani Yuliyanti (2010) bahwa variabel solvabilitas tidak berpengaruh signifikan terhadap audit delay, sedangkan hasil penelitian Rangga Fahmi (2018) menyatakan bahwa variabel solvabilitas berpengaruh signifikan terhadap audit delay. Hasil penelitian Setiawan (2010) menyatakan bahwa Ukuran KAP berpengaruh signifikan terhadap terhadap audit delay, berbeda dengan hasil penelitian yang dilakukan oleh Andi (2011) bahwa Ukuran KAP tidak berpengaruh signifikan terhadap audit delay.

Berdasarkan fenomena

fenomena di atas penulis melakukan penelitian ini, dengan mengambil objek penelitian perusahaan manufaktur sektor industry barang konsumsi yang terdaftar di Bursa Efek Indonesia (BEI) tahun 2017 - 2019

\subsection{Batasan Masalah}

1. Variabel independen yang digunakan adalah tingkat profitabilitas, tingkat solvabilitas, dan ukuran KAP, sedangkan variabel dependennya adalah audit delay.

2. Objek yang diteliti adalah perusahaan manufaktur sector industry barang konsumsi yang terdaftar di Bursa Efek Indonesia (BEI) Periode 2017 - 2019.

\subsection{Rumusan Masalah}

1. Apakah profitabilitas berpengaruh secara parsial terhadap audit delay pada perusahaan manufaktur sektor industri barang konsumsi yang terdaftar di Bursa Efek Indonesia (BEI) periode 2017 - 2019?

2. Apakah solvabilitas berpengaruh secara parsial terhadap audit delay pada perusahaan manufaktur sektor industri barang konsumsi yang terdaftar di Bursa Efek Indonesia (BEI) periode 2017 -2019?

3. Apakah ukuran KAP berpengaruh secara parsial terhadap audit delay pada perusahaan manufaktur sektor industri barang konsumsi yang terdaftar di Bursa Efek Indonesia (BEI) periode 2017 -2019?

4. Apakah profitabilitas, solvabilitas, dan ukuran KAP, berpengaruh secara bersama-sama(simultan) terhadapaudit delay pada perusahaan manufaktur sektor industri barang konsumsi yang terdaftar di Bursa Efek Indonesia (BEI) periode 2017 -2019?

\subsection{Tujuan Peneltian}

1. Untuk mengetahui apakah terdapat pengaruh profitabilitas terhadap audit delay pelaporan keuangan pada perusahaan manufaktur sector barang konsumsi yang terdaftar di Bursa efek Indonesia (BEI) tahun 2017 - 2019.

2. Untuk mengetahui serta menganalisis apakah terdapat pengaruh solvabilitas terhadap audit delay pada perusahaan manufaktur sector barang konsumsi yang terdaftar di Bursa Efek Indonesia tahun 2017 - 2019

3. Untuk mengetahui serta menganilisis apakah terdapat pengaruh ukuran KAP terhadap audit delay pelaporan keuangan pada perusahaan manufaktur sector barang konsumsi yang terdaftar di Bursa Efek Indonesia tahun 20172019.

4. Untuk mengetahui serta menganalisis apakah terdapat pengaruh dari profitabilitas, solvabilitas, dan ukuran KAP, terhadap audit delaypelaporan laporan keuangan pada perusahaan manufaktur sektor barang konsumsi 
yang terdaftar di Bursa Efek Indonesia ( BEI) periode 2017 2019

\subsection{Kerangka Konsep}

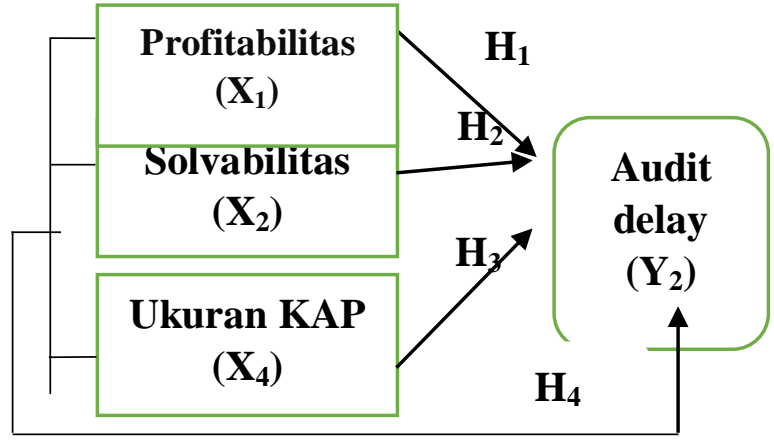

Sumber : diolah oleh penulis 2020

Gambar 1 : Kerangka Konsep

\subsection{Hipotesis}

Berdasarkan uraian teoritis dan kerangka pemikiran di atas, maka penulis merumuskan hipotesis penelitian :

$\mathbf{H}_{1}$ : Profitabilitas berpengaruh secara parsial terhadap audit delay peaporan keuangan pada perusahaan manufaktur sector barang konsumsi yang terdaftar di Bursa Efek Indonesia (BEI) tahun 2017 - 2019

$\mathbf{H}_{2}$ : Solvabilitas berpengaruh secara parsial terhadap audit delay pelaporan keuangan pada perusahaan manufaktur sector barang konsumsi yang terdaftar di Bursa Efek Indonesia (BEI) tahun 2017 - 2019

$\mathbf{H}_{3}$ : Ukuran KAP berpengaruh secara parsial terhadap audit delay pada perusahaan manufaktur sector barang konsumsi yang terdaftar di Bursa Efek Indonesia tahun 20172019.

$\mathbf{H}_{\mathbf{4}}$ : Profitabilitas, solvabilitas, dan ukuran KAP berpengaruh secara bersama-sama (simultan) terhadap audit delay pelaoran keuangan pada perusahaan manufaktur sector barang konsumsi yang terdaftar di Bursa Efek Indonesia tahun 2017 - 2019

\section{TINJAUAN PUSTAKA}

\subsection{Audit Delay}

Jangka penyelesaian audit laporan keuangan sampai menghasilkan pendapat (opini) yang telah ditentukan oleh Bapepam-LK yaitu 3 (tiga) bulan setelah tahun buku berakhir dan apabila melebihi batas yang telah diisyaratkan kondisi laporan keuangan mengalami audit delay. Audit delay sering diartikan sebagai istilah dalam keterlambatan dalam penyelesaian audit laporan keuangan.

Audit delay $=$ Tanggal Laporan Audit - Tanggal Penutupan Tahun Buku

\subsection{Profitabilitas}

Profitabilitas merupakan kemampuan suatu perusahaan dalam memperoleh keuntungan atau laba untuk mensejahterahkan pihak/pegawai yang berhubungan dengan perusahaan tersebut. Penelitian ini akan menghitung profitabilitas dengan rasio Return On Asset (ROA).

$$
\mathrm{ROA}=\frac{\text { Laba Bersih }}{\text { Total Asset }}
$$

\subsection{Solvabilitas}

Solvabilitas merupakan rasio yang digunakan untuk mengukur kemampuan perusahaan dalam memenuhi seluruh kewajibannya-kewajibannya.

Dalam hal ini rasio solvabilitas yang digunakan rasio DAR (Dabt to Equity Ratio) dengan rumus :

$$
D A R=\frac{\text { Total Hutang }}{\text { Total Aset }}
$$




\subsection{Ukuran KAP}

Karina Mutiara Dewi mendefinisikan Kantor Akuntan Publik (KAP) suatu organisasi Akuntan Publik yang memiliki izin sesuai undangundang dan melakukan praktek dan memberi jasa secara professional (Karina Mutiara Dewi, 2013)

Untuk mengukur Ukuran KAP menggunakan variabel dummy. Variabel dummy merupakan variabel buatan dengan dua kategori atau kategori yang berbeda yang menetapkan angka " 0 " dan "1" (Parjiono, dkk 2018:178). Kategori 1 untuk perusahaan yang menggunakan KAP berafiliasi dengan the big four dan kategori 0 untuk perusahaan yang tidak berafiliasi dengan the big four

\section{METODE PENELITIAN 3.1 Metode Pengumpulan Data Metode Kepustakaan}

Metode pustaka adalah metode pengumpulan data dengan cara mengumpulkan sejumlah buku - buku yang berkenaan dengan masalah dan tujuan penelitian.

\section{Metode Lapangan}

Metode lapangan adalah metode pengumpulan data dengan cara menyurvei objek penelitian dengan tujuan mencari bahan-bahan yang lebih tepat dan bahan-bahan yang lebih banyak. Metode lapangan terdiri dari 2 (dua), yaitu:

a. Observasi

Observasi adalah teknik untuk mengumpulkan data di lapangan yang dilakukan secara langsung kemudian hasil pengamatan itu akan dicantumkan dalam catatan.

b. Dokumentasi

Dokumentasi merupakan teknik dalam pengumpulan data dengan cara memahami data-data melalui dokumen ataupun catatan yang ada sesuai dengan yang diperlukan.

Metode pengumpulan data pada penelitian ini dilakukan melalui pencarian data sekunder dengan kepustakaan dan teknik dokumentasi.

\subsection{Metode Analisis Data dan Uji \\ Hipotesis}

\section{Statistik Deskriptif}

Data yang dikumpulkan dianalisa dengan cara mendiskripsikan dan menggambarkan tidak bermaksud untuk mengambil kesimpulan. Metode ini hanya bermaksud untuk untuk menguraikan dan memberikan keterangan terhadap suatu data atau keadaan.

\section{Metode Regresi Logistik}

Pada penelitian ini, pengujian dilakukan dengan analisis regresi logistik, yaitu regresi yang digunakan untuk menguji sampai sejauh mana probabilitas terjadinya variable dependen dapat diprediksi oleh variable independen.Rumus Metode regresi logistic :

$\mathrm{Y}=\operatorname{Ln} \frac{p}{1-p=}=\mathrm{a}+\beta_{1} \mathrm{X}_{1}+\beta_{2} \mathrm{X}_{2}+\beta_{3} \mathrm{X}_{3}+\mathrm{e}$

(Ghozali, 2016:324)

Keterangan :

$\mathrm{Y} \quad=$ Audit delay

a $\quad=$ Konstanta

$\mathrm{X}_{1} \quad$ = Profitabilitas

$\mathrm{X}_{2} \quad=$ Solvabilitas

$\mathrm{X}_{3}=$ Ukuran KAP

$\beta_{1}-\beta_{3}=$ Koefisien Regresi Variabel Independen

e $\quad=$ Error of term / Gangguan

a) Menilai Kelayakan Model Regresi

Menurut Ghozali (2016:329) "kelayakan model regresi dinilai dengan menggunakan Hosmer 
and Lemeshow's Goodness of Fit Test". Hipotesis untuk menilai kelayakan model regresi dengan uji ini adalah sebagai berikut:

1. Jika nilai Hosmer-lemeshow signifikan atau lebih kecil dari 0.05 maka hipotesis nol ditolak dan model dikatakan tidak fit.

2. Jika nilai Hormer-lemeshow signifikan lebih besar dari 0.05 maka hipotesis nol diterima atau model fit dengan data.

\section{b. Model Fit dan keseluruhan Model ( Overall Model Fit)}

Uji ini untuk menilai apakah model yang dihipotesiskan telah fit dengan data atau tidak.Penilaian keseluruhan model (Overall Model Fit) dilakukan dengan membandingkan nilai antara -2Log Likelihood (-2LL) pada awal (Block Number $=0)$ dimana model hanya memasukkan nilai konstanta dengan nilai -2Log Likelihood (-2LL) pada akhir (Block number $=1$ ) dimana model hanya memasukkan nilai konstanta dan variabel bebas. Kriteria atau syarat yang digunakan pada pengujian ini adalah:

1. Apabila nilai -2Log Likehood (2LL) pada awal (Block Number = 0) lebih besar dengan nilai -2Log likelihood (-2LL) pada akhir (Block Number = 1) menandakan bahwa model regresi yang digunakan sudah baik atau dengan kata lain model yang dihipotesakan fit dengan data.

2. Apabila nilai -2Log Likehood (2LL) pada awal (Block Number = 0) lebih kecil dengan nilai -2Log likelihood (-2LL) pada akhir (Block Number = 1) menandakan bahwa model regresi yang digunakan belum baik atau dengan kata lain model yang dihipotesakan tidak fit dengan data.

\subsection{Uji Hipotesis}

Uji hipotesis dilakukan dengan analisis regresi logistik.Pengujian ini menggunakan t-test, F-test koefisien dan determinasi $(R 2)$.Model analisis ini yaitu pengujian variabel audit delay sebagai variabel dependen yang dijelaskan oleh variabel independen (profitabilitas, solvabilitas, dan, ukuran KAP).Estimaasi

Parameter menggunakan Maximum Likehood Estimation (MLE) (Ghozali, 2016:330).

Kriteria pengambilan keputusan adalah:

1. Jika nilai probabilitas (sig) $>0,05$ maka H0 diterima, yang berarti variable independen tidak berpengaruh signifikan terhadap variable dependen.

2. Jika nilai probabilitas (sig) $<0,05$ maka H0 ditolak, yang berarti bahwa varabel independen berpengaruh signifikan dengan variable dependen.

\subsubsection{Uji Parsial (Uji Wald)}

Uji Wald dilakukan untuk pengujian pengaruh masing-masing variabel independen terhadap variabel dependen secara parsial.

1. Merumuskan hipotesis null dan alternatif

a. $\mathrm{H0}: B 1=\beta 2=\beta 3=0$,

Artinya variabel $\mathrm{X} 1$, Variabel X2 dan Variabel X3 secara parsial tidak berpengaruh terhadap variabel $\mathrm{Y}$.

b. Ha : $\beta 1=\beta 2=\beta 3 \neq 0$, Artinya variabel $\mathrm{X} 1$, Variabel X2 dan Variabel X3 secara parsial tidak berpengaruh terhadap variabel $\mathrm{Y}$.

2. Menentukan kriteria pengujian hipotesis

a. Jika signifikansi $<0,05$, maka Ha diterima, artinya variabel independen mempunyai 
pengaruh signifikan terhadap variabel dependen.

b. Jika signifikansi > 0,05, maka H0 diterima, artinya variabel independen tidak mempunyai pengaruh signifikan terhadap variabel dependen.

\subsubsection{Uji Simultan (Omnibus Test of Model Coefficient)}

Pengujian omnibustest of model coefficient adalah pengujian hubungan regresi secara simultan dari variabelvariabel dependen yang bertujuan apakah secara bersama-sama seluruh variabel independen mempunyai pengaruh yang signifikan terhadap variabel dependen.

1. Merumuskan hipotesis null dan alternatif

a. $\mathrm{HO}: \beta 1=\beta 2=\beta 3=0$,

Artinya variabel $\mathrm{X} 1$, Variabel X2 dan Variabel X3 secara parsial tidak berpengaruh terhadap variabel $\mathrm{Y}$.

b. Нa : $\beta 1=\beta 2=\beta 3 \neq 0$,

Artinya variabel $\mathrm{X} 1$, Variabel X2 dan Variabel X3 secara parsial tidak berpengaruh terhadap variabel $\mathrm{Y}$.

2. Menentukan kriteria pengujian hipotesis

a. Jika signifikansi dari hasil omnibustest of model coefficient $<$ 0,05, maka $\mathrm{Ha}$ diterima.

b. Jika signifikansi omnibustest of model coefficient $>0,05$, maka $\mathrm{H} 0$ diterima

\subsubsection{Koefisien Determinasi}

(Nagelkerke R Square)

Cox and Snell's R Square merupakan ukuran yang mencoba meniru ukuran R2 pada multiple regression yang didasarkan pada teknik estimasi Likehood dengan nilai maksimum kurang dari 1 (satu) sehingga sulit untuk dinterpretasikan.
Negelkerke's R Square merupakan modifikasi dari koefisen Cox and Snell's untuk memastikan bahwa nilainya bervariasi dari 0 sampai 1 . Hal ini dilakukan dengan cara membagi nilai Cox and Snell's R2 dengan nilai maksimumnya. Nilai Nagelkerke' sR2 dapat dinterpretasikan seperti nilai R2 pada multiple regression (Ghozali, 2016:329).

\section{HASIL DAN PEMBAHASAN}

\subsection{Analisis Regresi Logistik}

Hasil pengujian model regresi logistik dapat dilihat pada tabel berikut:

Tabel 1: Hasil Uji Regresi Logistik

Variables in the Equation

Sumber: Hasil olahan SPSS 22

Dari hasil tabel 1 tersebut, maka persamaan regresi logistik dalam penelitian ini dapat diformulasikan dalam bentuk persamaan berikut ini:

$\mathrm{Y}=\frac{p}{1-p}=-0,701+16,710 \mathrm{X}_{1}+5,683 \mathrm{X}_{2}+$ $18,203 \mathrm{X}_{3}+\mathrm{e}$

Berdasarkan hasil persamaan diatas, maka hubungan masing-masing variabel independen tersebut terhadap audit delay dapat diinterpretasikan sebagai berikut:

a. Nilai konstanta $(\alpha)=-0,701$

Dari model logit diketahui bahwa konstanta sebesar -0,701, hal ini menunjukkan apabila nilai variabel

\begin{tabular}{|rr|r|}
\hline \multicolumn{2}{|c|}{ Model } & \multicolumn{1}{|c|}{ B } \\
\hline Step $1^{\mathrm{a}}$ & X1 & 16.710 \\
& X2 & 5.683 \\
& X3 & 18.203 \\
& Constant & -.701 \\
\hline
\end{tabular}

independen

(profitabilitas, solvabilitas, dan ukuran perusahaan) diasumsikan sama dengan nol, maka probabilitas perusahaan mengalami 
audit delay akan menurunsebesar 0,701 atau $70,1 \%$.

b. Koefisien regresi $\beta 1$ sebesar 16,710, artinya setiap kenaikan profitabilitas sebesar $1 \%$ akan diikuti kenaikan audit delay sebesar 16,710 dengan anggapan variabel independen yang lain dianggap sama dengan nol. Hubungan profitabilitas dengan audit delay memiliki hubungan yang positif.

c. Koefisien regresi $ß 1$ sebesar 5,683 artinya setiap kenaikan solvabilitas sebesar $1 \%$ akan diikuti kenaikan audit delay sebesar 5,683 atau sebesar 568,30\% dengan anggapan variabel independen yang lain dianggap sama dengan nol. Hubungan solvabilitas dengan audit delay memiliki hubungan yang positif.

d. Koefisien regresi $ß 1$ sebesar 18,203, artinya setiap kenaikan ukuran KAP sebesar $1 \%$ akan diikuti kenaikan audit delay sebesar 18,203 dengan anggapan variabel independen yang lain dianggap sama dengan nol. Hubungan ukuran KAP dengan audit delay memiliki hubungan yang positif.

\subsection{Pengujian Model}

\section{Menilai Kelayakan Model Regresi}

Hasil pengujian Hosmer and Lemeshow's Goodness of Fit Test yang diukur dengan nilai Chi-Square dengan tingkat $(\alpha) 5 \%$.adalah sebagai berikut:

Tabel 2:Hosmer and Lemeshow

\begin{tabular}{|l|r|r|r|}
\hline Step & Chi-square & df & Sig. \\
\hline 1 & 2.961 & & 8 \\
\hline
\end{tabular}

Sumber: Hasil olahan SPSS 22

Dari tabel 2 diatas menunjukkan bahwa nilai statistic Chi-square dari hasil uji Hosmer and Lemeshow's Test adalah sebesar 2,961 dengan tingkat signifikansi sebesar 0,937 > dari 0,05.
Dari hasil pengujian tersebut dapat diambil kesimpulan bahwa model yang digunakan mampu/dapat memprediksi nilai observasinya atau model yang dihipotesaskan telah fit dengan data.

\section{Menilai Keseluruhan Model (Overall Model Fit)}

Uji ini digunakan untuk menilai model yang telah dihipotesakan telah fit atau tidak dengan data dilakukan pengujian dengan hipotesis.

Hasil Pengujian yang dilakukan dengan membandingkan nilai antara 2Log Likelihood pada awal (blok number $=0$ ) dengan nilai $-2 \log$ Likelihood pada akhir (blocknumber = 1), yang ditunjunkkan pada table berikut:

Tabel 3: Likehood Block 0 dan Block 1

\begin{tabular}{|l|c|}
\hline & $\begin{array}{c}-2 \text { Log } \\
\text { likelihood }\end{array}$ \\
\hline Iteration & 17.108 \\
Block 0 & 12.817 \\
\hline
\end{tabular}

Sumber: Data olahan SPSS 22

Tabel 3 di atas adalah Iteration History (Block 0) yang merupakan -2 Log Likelihood awal yaitu sebesar 17,108.Nilai yang tertera dalam tabel digunakan untuk dibandingkan dengan nilai pada Iteration History (Block 1) yang merupakan -2 Log Likelihood akhir. Adanya pengurangan atau nilai antara -2 Log Likelihood awal lebih besar dengan -2 Log Likelihood akhir menunjukan bahwa yang dihipotesiskan fitdengan data.

Nilai -2 Log Likelihood akhir (Block 1) adalah sebesar 12,817. Hal ini berarti nilai -2 Log Likelihood awal (Block 0) lebih besar dari nilai -2 Log Likelihood akhir (Block 1) yaitu sebesar $17,180>12,817$. Berdasarkan hasil tersebut terjadi pengurangan atau mengalami penurunan antara $-2 \log$ Likelihood awal(Block 0) dengan -2 
Log Likelihood akhir (Block 1) mengindikasikan bahwa model yang di hipotesiskan fit dengan data.

\subsection{Pengujian Hipotesis Hasil Uji Parsial (Uji Wald)}

Hasil uji Wald mengenai pengaruh (profitabilitas, solvabilitas dan ukuran KAP) secara parsial terhadap audit delay dapat dilihat pada tabel berikut:

Tabel 4 : Hasil Uji Wald

\begin{tabular}{|ll|r|r|r|}
\hline \multicolumn{4}{|c|}{ Variables in the Equation } \\
\hline & & \multicolumn{1}{|c|}{ B } & \multicolumn{1}{c|}{ Wald } & Sig. \\
\hline Step & X1 & 16.710 & .663 & .415 \\
$1^{\text {a }}$ & X2 & 5.683 & 1.187 & .276 \\
& X3 & 18.203 & 2.068 & .048 \\
& Cons & -.701 & .000 & .795 \\
& tant & - & & \\
\hline
\end{tabular}

Dari tabel 4 diatas, pengaruh variabel independen (profitabilitas, solvabilitas dan ukuran KAP secara parsial terhadap variabel dependen (audit delay) dapat dijelaskan sebagai berikut:

1. Variabel profitabilitas

memiliki nilai Wald sebesar 0,663 dengan nilai signifikansi sebesar $0,415>0,05$ dengan demikian dapat disimpulkan bahwa profitabilitas tidak berpengaruh secara signifikan terhadap audit delay.

2. Variabel solvabilitas (X2) memiliki nilai Wald sebesar 1,187 dengan nilai signifikansi sebesar $0,276>$ 0,05 dengan demikian dapat disimpulkan bahwa solvabilitas tidak berpengaruh terhadap audit delay.

3. Variabel ukuran KAP (X3) memiliki nilai Wald sebesar 2,068 dengan nilai signifikansi sebesar $0,048<0,05$ dengan demikian dapat disimpulkan bahwa ukuran
KAP berpengaruh secara signifikan terhadap audit delay.

\section{Hasil Uji Simultan (Omnibus Test Of Model Coefficient)}

Hasil pengujian pengaruh variabel independen (profitabilitas, solvabilitas dan ukuran KAP) secara simultan terhadap variabel independen (audit delay) dapat dilihat dari tabel Omnibus Test Of Model Coefficient sebagai berikut:

Tabel 5: Hasil Uji Simultan

Omnibus Tests of Model

Coefficients

\begin{tabular}{|ll|r|r|r|}
\hline & & $\begin{array}{c}\text { Chi- } \\
\text { square }\end{array}$ & Df & Sig. \\
\hline Step 1 & Step & 4.291 & 3 & .032 \\
& Block & 4.291 & 3 & .032 \\
& Model & 4.291 & 3 & .032 \\
\hline
\end{tabular}

Sumber: Hasil Olahan SPSS 22

Dari tabel 5 diatas, nilai statistik chi-square yaitu sebesar 4,291 dengan nilai signifikansi sebesar $0,032<0,05$ artinya variabel independen (profitabilitas, solvabilitas dan ukuran KAP) berpengaruh secara bersama /simultan terhadap audit delay.

\section{Hasil Uji Koefisien Determinasi (Nagelkerke R Square)}

Untuk melihat seberapa besar variabel (profitabilitas, solvabilitas dan ukuran KAP) mampu menjelaskan dan mempengaruhi variabel dependen (audit delay) dapat dilihat dari tabel berikut:

Tabel 6: Koefisien Determinasi

\begin{tabular}{|l|r|r|r|}
\multicolumn{5}{c}{ Model Summary } \\
\hline Step & $\begin{array}{c}-2 \text { Log } \\
\text { likelih } \\
\text { ood }\end{array}$ & $\begin{array}{c}\text { Cox \& } \\
\text { Snell R } \\
\text { Square }\end{array}$ & $\begin{array}{c}\text { Nagelker } \\
\text { ke R } \\
\text { Square }\end{array}$ \\
\hline 1 & 12.817 & .076 & .281 \\
\hline
\end{tabular}

Sumber: Hasil Olahan SPSS 22

Dari tabel 6 diatas, nilai nagelkerke R Square sebesar 0,281 atau 
$28,10 \%$ artinya variabel independen (profitabilitas, solvabilitas dan ukuran KAP) dapat menjelaskan variabel dependen (audit delay) sebesar 28,10\% dan sisanya sebesar $71,90 \%$ dijelaskan variabel lain yang tidak dimasukkan dalam model penelitian.

\subsection{Interpretasi Hasil}

\section{Pengaruh Profitabilitas Terhadap Audit Delay}

Hasil pengujian regresi logistik profitabilitas pada penelitian ini menyatakan bahwa profitabilitas secara parsial memiliki nilai Wald sebesar 0,663 dengan nilai signifikansi 0,415 > 0,05 , maka $\mathrm{H} 0$ diterima artinya profitabilitas tidak berpengaruh terhadap audit delay. Dalam hal ini konsisten dengan penelitian yang dilakukan oleh Jun Peramita Aritonang (2019) dan Rangga Fahmi Hakiki (2018) dimana keduanya menemukan bukti empiris dimana profitabilitas tidak berpengaruh terhadapaudit delay. Hasil yang tidak signifikan dalam peneltian ini menunjukkan bahwa profitabilitas tidak mempengaruhi terjadinya audit delay dalam pelaporan keuangan tetapi hanya dianggap sebagai penyampaian informasi bahwa perusahaan berada dalam kondisi yang mengalami profit atau memiliki laba.

\section{Pengaruh Solvabilitas Terhadap Audit Delay}

Hasil pengujian regresi logistik solvabilitas pada penelitian ini menyatakan bahwa solvabilitas secara parsial memiliki nilai Wald sebesar 1,187 dengan nilai signifikansi sebesar $0,276>0,05$, maka H0 diterima artinya solvabilitas tidak berpengaruh signifikan terhadap audit delay. Hal ini konsisten dengan penelitian yang dilakukan oleh Jun Peramita Aritonang (2019) dimana menemukan bukti empiris bahwa solvabilitas tidak berpengaruh signifikan terhadap audit delay. Hasil peneltian ini tidak konsisten dengan penelitian yang dilakukan oleh Karina Mutiara Dewi (2013) yang menyatakan bahwa solvabilitas berpengaruh signifikan terhadap audit delay. Hasil yang tidak signifikan dalam peneltian ini menunjukkan bahwa solvabilitas tidak mempengaruhi terjadinya audit delay dalam pelaporan keuangan tetapi dianggap sebagai penyampaian bahwa perusahaan tidak memiliki kemampuan atau memiliki kemampuan dalam melunasi hutangnya yang dilihat dan dibandingkan dari total aset yang dimiliki perusahaan dimana solvabilitas perusahaan yang tinggi maka kemampuan perusahaan dalam melunasi hutangnya yang dilihat dari total asetnya semakin kecil, sebaliknya jika solvabilitas perusahaan yang rendah maka kemampuan perusahaan melunasi hutangnya yang dilihat dari total asetnya semakin besar.

\section{Pengaruh Ukuran KAP Terhadap Audit delay}

Hasil pengujian regresi logistik ukuran KAP pada penelitian ini menyatakan bahwa ukuran KAP secara parsial memiliki nilai Wald sebesar 2,068 dengan nilai signifikansi sebesar $0,048<0,05$, maka H0 ditolak artinya ukuran KAP berpengaruh signifikan terhadap audit delay. Hasil penelitian ini konsisten dengan penelitian yang dilakukan oleh oleh Karina Mutiara Dewi (2013) yang menyatakan bahwa ukuran KAP berpengaruh signifikan terhadap audit delay. Hasil peneltian ini tidak konsisten dengan penelitian yang dilakukan Jun Peramita Aritonang (2019) dimana menemukan bukti empiris bahwa ukuran KAP tidak berpengaruh signifikan terhadap audit delay. Hasil yang signifikan dalam 
peneltian ini menunjukkan bahwa ukuran KAP mempengaruhi terjadinya audit delay dalam pelaporan keuangan dimana semakin bagus tingkat ukuran KAP yang digunakan perusahaan maka semakin mempercepat dalam menyampaikan laporan keuangan.

\section{Pengaruh Profitabilitas, Solvabilitas dan Ukuran KAP terhadap Audit Delay}

Hasil pengujian menunjukkan bahwa profitabilitas, solvabilitas dan ukuran KAP secara bersama-sama yaitu dengan pengujian Omnibus Test Of Model Coefficient dengan nilai statistik chi-square yaitu sebesar 4,291 dengan nilai signifikansi sebesar $0,032<0,05$, maka H0 ditolak dan H1 diterima artinya bahwa profitabilitas, solvabilitas dan ukuran KAP berpengaruh secara bersama-sama terhadap audit delay pada perusahaan manufaktur sector industry barang konsumsi yang terdaftar di BEI 2017-2019. Hasil penelitian ini dapat diinterpretasikan bahwa apabila profitabilitas, solvabilitas dan ukuran KAP bertambah secara bersama-sama akan mempengaruhi terjadinya audit delay pada suatu perusahaan.

\section{SIMPULAN DAN SARAN 5.1 Simpulan}

1. Profitabilitas(X1) tidak berpengaruh terhadap audit delay, sehingga peneliti menyimpulkan bahwa besar kecilnya keuntungan yang dimiliki perusahaan tidak mempengaruhi audit delay pada suatu perusahaan.

2. Solvabilitas (X2) tidak berpengaruh terhadap audit delay, sehingga peneliti menyimpulkan bahwa besar kecilnya kemampuan perusahaan melunasi hutangnya tidak mempengaruhi audit delay pada suatu perusahaan.

3. Ukuran KAP (X3) berpengaruh terhadap audit delay, sehingga peneliti menyimpulkan bahwa jika laporan perusahaan diaudit oleh KAP yang berafiliasi big four atau non big four akan mempengaruhi terjadinya audit delay pada suatu perusahaan.

4. Profitabilitas, solvabilitas dan ukuran KAP berpengaruh secara bersama-sama terhadap audit delay, sehingga peneliti menympulkan bahwa jika profitabilitas, solvabilitas dan ukuran KAP bertambah secara bersama-sama akanmempengaruhi terjadinya audit delay pada suatu perusahaan.

5. Tingkat kejelasan variabel profitabilitas, solvabilitas dan ukuran KAP dalam peneltian ini menunjukkan bahwa tindakan audit delay ini lemah yaitu dilihat dari nilai nagelkerke $\mathrm{R}$ Square yaitu sebesar 0,281 atau $28,10 \%$ dan sisanya sebesar $71,90 \%$ dijelaskan variabel lain yang tidak terdapat dalam model penelitian ini.

\section{Keterbatasan Penelitian}

1. Penelitian ini hanya menggunakan perusahaan manufaktur sektor industri barang konsumsi yang terdaftar di Bursa Efek Indonesia periode 2018-2019.

2. Penelitian ini terbatas pada tiga variabel yang digunakan, yaitu profitabilitas, solvabilitas dan ukuran KAP dalam mempengaruhi audit delay pelaporan keuangan.

\subsection{Saran}

1. Untuk penelitian selanjutnya disarankan untuk memilih populasi dan sampel yang lebih banyak atau memilih sektor agar hasil penelitian dapat digeneralisasikan pada setiap sektor seperti sektor industri dasar dan kimia, sektor perbankan dan sektor lainnya. 
2. Untuk penelitian selanjutnya disarankan untuk menambah variabel yang memungkinkan dapat mempengaruhi audit delay seperti laba/rugi perusahaan, Financial Leverage, umur perusahaan, opini auditor dan lainnya.

3. Untuk penelitian selanjutnya disarankan utnuk menggunakan pengukuran lain yang tidak digunakan dalam peneltian ini untuk mendapatkan hasil yang lebih akurat.

\section{DAFTAR PUSTAKA}

Akbar, Taufiq. 2019. Kajian Kinerja profitabilitas Bank Pada Persepktif Bank Umum.Surabaya: Uwais Inspirasi Inonesia.

Ardiyos. 2010. Kamus Besar Akunatnsi. Jakarta: Citra Harta Prima.

Dewi, Karina Mutiara. 2013. Analisis Faktor - Faktor Yang Mempengaruhi Ketepatan Waktu Dan Audit Delay Penyampaian Laporan Keuangan. Jurnal.Volume 2. No. 2)

Djarwanto Ps. 2001.Mengenal Beberpa UJi Statistik Dalam Penelitian. Yogyakarta: Liberiti.

Ghozali, Imam. 2016. Aplikasi Analisis Multivariet dengan Program IBM SPSS 20.Semarang: Universitas Diponegoro.

Ikatan Akuntan Indonesia. 2015.

Pernyataan standar Akuntansi Keuangan (PSAK) No.1 Penyajian Laporan Keuangan. Jakarta: Salemba Empat.

Kasmir. 2017. Analisi Laporan Keuangan. Jakarta: Rajawali Pers.

Parjiono, dkk.2018. Kebijakan Multilateral dan Pembangunan Ekonomi
Indonesia. Jakarta: Gramedia pustaka Utama.

Purnomo, Aldy Rochmat. 2016. Analisis Statistik Ekonomi dan Bisnis dengan SPSS. Yogyakarta: Wade Group.

Seftianne. 2011. Faktor - Faktor Yang Mempengaruhi Stuktur Modal Pada Perusahaan Publik Sektor Manufaktur. Jurnal Bisnis dan Akuntansi. Volume 13. No. 1)

Subekti, Imam 2012. Relevansi Nilai Atas Informasi Akuntansi, Struktur Kepemilikan Saham, dan Afiliasi. Jakarta : Pradnya Paramita.

Sudana, I Made. 2012. Manajemen Keuangan Perusahaan Teori dan Praktik.Jakarta: Erlangga.

Sugiyono. 2018. Metode Penelitian Kuantitatif, Kualitatif, dan $R \& D$. Bandung: Alfabeta. 